(2) Open Access Full Text Article

\title{
Investigating Knowledge, Attitude, and Beliefs Regarding Placebo Interventions in Clinical Practice: A Comparative Study of Nursing and Medical University Students
}

This article was published in the following Dove Press journal:

Advances in Medical Education and Practice

Hala Mohamed Mohamed Bayoumy (D) $^{1-3}$ Ghada Eissa Almuwallad (D) ${ }^{4}$ Ashwag Othman Eissa (iD ${ }^{5}$

'Department of Nursing, Cairo University, Gizah, Egypt; ${ }^{2}$ Department of Nursing, King Saud Bin Abdul Aziz University for Health Sciences, Jeddah, Saudi Arabia; ${ }^{3}$ King Abdullah International Medical Research Center; King Saud Bin Abdul Aziz University for Health Sciences, Jeddah, Saudi Arabia; ${ }^{4}$ Pediatric Intensive Care Unit, King Faisal Specialist Hospital and Research Center, Jeddah, Saudi Arabia; ${ }^{5}$ Medical-Surgical Intensive Care Unit, King Faisal Specialist Hospital and Research Center, Jeddah, Saudi Arabia
Correspondence: Hala Mohamed Mohamed Bayoumy P.O.Box. 95I5, Jeddah 21423, Saudi Arabia

Tel +966565609919

Email hamr77@hotmail.com
Background: Placebo interventions are commonly used in medical practice for alleviating symptoms of illnesses. Placebo is considered a pseudo-medication and its use is debatable ethically, professionally, and legally. Despite that there is also a lack of evidence on understanding of placebo interventions among health profession students. Further, no previous studies have been conducted to investigate whether future nurses and physicians differ in their knowledge, attitudes, and beliefs regarding placebo intervention.

Materials and Methods: A comparative cross-sectional study was carried out for exploring knowledge, attitude, and beliefs about placebo interventions among a convenient sample of 187 medical and nursing students at King Saud bin Abdulaziz University for Health Sciences. Data were collected using a sociodemographic data sheet and a 32-item placebo knowledge, beliefs, and attitude scale, which was developed from the evidence-based literature. Validity and reliability were ensured through utilizing a panel of experts and internal consistency analysis.

Results: Overall mean participants' knowledge score was $7.68 \pm 2.07$ (out of 15). Nursing students showed significantly higher knowledge than medical students $(P=0.028)$. More nursing than medical students believed in the effectiveness of placebo $(P<0.001)$. Medical students had a stronger belief that the placebo effect is mental, while nursing students reported that it is both mental and physiologic $(P<0.006)$. Concerning placebo attitude, medical students significantly pointed out that it should generally be prohibited and should not be permitted unless research supports its use $(P<0.001)$. Both groups agreed that impure placebo intervention involves deception.

Conclusion: Participants' overall placebo knowledge was low. Inconsistencies in attitude and beliefs were shown among students. Current study findings offered a unique opportunity to better study misunderstandings for placebo, which might open the gate for misuse and place patients at risk of deception. Additionally, study findings were imperative as a relevant evidence-based recommendation for nursing and medical educators could be achieved.

Keywords: placebo, knowledge, attitude, beliefs

\section{Introduction}

Placebo interventions are commonly used in medical practice across different countries ${ }^{1}$ to improve symptoms and promote well-being. ${ }^{2-5}$ International research studies report an incidence of use ranging from $17 \%$ to $99 \%$ among general practitioners (GPs). ${ }^{2}$ Linde et $a 1,{ }^{6}$ in a meta-analysis including 16 studies from 13 
countries, reported that the percentage of GPs having used any form of placebo at least once in their career ranged from $29 \%$ to $97 \%$, in the last year at least once from $46 \%$ to $95 \%$, at least monthly from $15 \%$ to $89 \%$, and at least weekly from $1 \%$ to $75 \%$. In Saudi Arabia; Al-Jumaih et al ${ }^{7}$ revealed that Saudi prescription of a placebo is lower than is reported elsewhere.

Despite its common use, placebo intervention is considered debatable in many aspects: professionally, ethically, and legally. Controversies surround definitions of placebo. It is considered a pseudo-medication which does not contain any components to improve or treat patient's problems. ${ }^{2}$ Placebos are defined as substances and interventions that lack specific efficacy in treating a patient's condition based on the inherent properties of the treatment. 8,9

Regardless the lack of research evidence on placebo mechanism of action and absence of clear justification for improvement experienced after its administration, ${ }^{4}$ placebo can have significant effects on patient's medical and psychological outcomes. ${ }^{10}$ These effects are defined as "the advantageous physiological or psychological changes associated with the use of inert medication, or therapeutic symbols inside a healthcare encounter". ${ }^{11}$ The effects following placebo use do not rest on the administration of "inert" substances, but can be attributed to the general psychosocial circumstances around the remedy. ${ }^{12}$ Consequently, Groll ${ }^{13}$ and Colloca et al $^{14}$ considered placebo as a treatment that induces a cure through brainmind-body interactions. Cadorin et $\mathrm{al}^{15}$ and Palese et $\mathrm{al}^{16}$ showed that recent research should focus on evaluating the effect of contextual factors (CFs), defined as interventions without a specific effect on the condition being treated, but with a possible nonspecific effect, as influential triggers in investigating outcome(s) of placebo. Cadorin et $\mathrm{al}^{15}$ emphasized that CFs are used frequently in clinical practice among nursing students to optimize clinical outcomes through promoting placebo effects. These contextual factors have been identified at individual, psychological, and neurobiological levels. ${ }^{16}$ Generally, placebo affects how patients perceive their condition and drive the body chemical process leading to relief of symptoms with no effect on the disease itself.

Furthermore, Kaptchuk ${ }^{17}$ drew attention to the idea that placebo effects appear to be more a neurological occurrence that results from constantly searching neurological systems attending to sensory, motor, affective, and cognitive stimuli in the context of an embodied and imaginative ritual performance of healing. These factors are translated into a cascade of psychoneuroimmunoendocrine events capable of generating placebo effects and eliciting expectations and emotions. ${ }^{16}$ As explained by Palese et al, ${ }^{16}$ placebo response is a multifaceted psychoneurobiological phenomena in which behavioral and neurophysiological changes arise subsequent to an interaction between the patient and the health care context.

Professional debates behind placebo is not only limited to the unexplained mechanism of action but also efficacy associated with different types of placebo interventions used in clinical practice. Placebo effects are produced by administration pure placebo or through administering an active treatment (impure placebo). ${ }^{8}$ Utilization of saline and sugar pills, saline injections, and prepared placebo tablets are identified as pure placebo, ${ }^{2}$ while treatment interventions that have a specific active constituent that is known to be effective in conditions other than the condition being treated are known as impure placebos. ${ }^{8}$ Pure placebo is often used on a basic belief that if it will not benefit, it is going to do no harm, while an impure placebo inappropriately reveals the complex practice situations of applying interventions which are not supported by scientific evidence. ${ }^{2}$ Concerns therefore have been raised about using placebos as treatments, as they often involve deception. $^{5}$

Previous research studies reported that the use of nonspecific interventions far outperformed the use of pure placebos. $^{2,6,18}$ The proportion of hospital nurses reporting use of (mainly pure) placebos (51\% to $100 \%$ in eight studies) was higher than in a physicians' surveys. ${ }^{2}$ Clinical observation shows that physicians do select impure placebos for use rather than pure placebos, a matter that is considered disturbing as most ethical debates and professional policies focus on pure placebos. ${ }^{18}$

Several ethical problems and moral challenges are associated with the use of placebo as treatment in a clinical practice. ${ }^{19}$ Doing no harm is an often reported reason in cases when pure placebos are used, while an impure placebo usually reflects the complex situations in which healthcare professionals apply interventions which are not supported by scientific evidence. ${ }^{2}$ Evidence suggests that placebo response is strongest when the patient is not aware that they are receiving placebo. Pugh ${ }^{19}$ suggests that in order for placebos to be fully effective, the patient must have a positive expectation of the treatment benefit; accordingly, it seems that physicians must obscure the fact that the treatment they are prescribing is an inert placebo. In light of this, concerns have been raised about using placebos as treatments, as they often involve 
deception. ${ }^{20}$ Another view expounded holds that, since placebo treatment promotes positive expectations on the part of patients, this by itself is a justification to consider its use as ethically acceptable. ${ }^{7}$

Stetler ${ }^{21}$ added that research outcomes support a direct, unmediated impact of preliminary expectations on later placebo response. The preliminary expectations appear to be vital as they are positively related with higher patient's adherence. Clinicians ought to think about consolidating patients' anticipations at the start of treatment, as this may enhance adherence, facilitating patient's exposure to effective therapy, and enhance the non-specific effects of treatment which leads to increasing health benefits. ${ }^{21}$ Placebos work with the aid of altering self-healing capabilities and by using manipulating contextual element, ${ }^{1}$ placebo science therefore needs to have focus studies of psychosocial factors, such as expectations, suggestions, symbolic thinking, framing, and cultural influences. ${ }^{18}$ There are therefore extreme controversies on ethical use of placebo.

An important consideration is whether placebo interventions can be used successfully without deceit. ${ }^{4}$ Withholding information about possible negative side effects also deprives patients of transparent disclosure and the ability to make an informed decision. This poses a more complicated ethical dilemma between the principles of respect for autonomy and beneficence. ${ }^{4}$ Fässler et $\mathrm{al}^{1}$ therefore emphasized that proper communication serves the partnership between the patient and healthcare providers and maintains patients' trust. Hull et $\mathrm{al}^{22}$ examined the attitudes of patients about the use of placebo in healthcare practice, most patients favorably regarded placebo treatment and valued honesty and transparency, suggesting that healthcare providers should discuss with patients their values and attitudes about the appropriateness of the usage of treatments that promote placebo responses. Developing general guiding rules that direct attention to possible pitfalls associated with the use of placebo might also be helpful.

There is a plethora of review articles and an increasing number of laboratory and clinical studies dealing with placebo and placebo effects, however empirical investigations on the current use of placebos in clinical practice and on the respective attitudes of healthcare professionals, students, or patients are sparse. ${ }^{2}$ Baldwin et $\mathrm{al}^{23}$ explored the attitudes of trainee surgeons towards placebo. The majority of trainees believe that the placebo effect is real with therapeutic benefits. Sixty percent of respondents agree that placebo can be used outside of research, most commonly, to distinguish between organic and nonorganic symptoms and used for pain management. They are mainly concerned about the risk of side effects associated with the use of placebo and prefer placebo interventions with minimal invasiveness. Seventy-three percent of respondents would recruit patients into the proposed randomized controlled surgical trial.

Despite nursing's modern focus on evidenced-based practice and the recent popularity of placebo research, the placebo effect is notably under-represented in the nursing literature and that physician publications seem to be more tolerant of research regarding the clinical use of placebo. ${ }^{4}$ This could possibly be explained in the light of inherited traditional view of placebos as deceitful and unethical. Views and attitudes on placebos use differ considerably among individuals, both among healthcare professionals and patients. In particular, the studies using qualitative methods show that attitudes towards placebo use are complex, and often cause a dilemma for healthcare providers which could influence their practice. ${ }^{2}$

Medical students receive little education about placebos which would explain the lack of understanding of the placebo effect. Many medical students confuse placebos with what they learn in "physicianship" (ie, courses focusing on the "softer" issues of medicine). Consequently, tomorrow's clinicians expect placebos to exert a minor effect. ${ }^{24}$ Utilization of placebo interventions in providing healthcare services for patients thus should be an area of major concern for health profession educators. ${ }^{25}$ The research by Colloca et $\mathrm{al}^{14}$ has partially made clear the role of how patients' expectations and the quality of physician-patient communication can influence the efficacy of interventions and overall clinical outcomes, accordingly, they emphasized the need to incorporate the placebo effect in the core clinical practice curriculum of all health practitioners.

The medical community should start an open discussion regarding the relative virtues and inadequacies of placebos in medicine because healthcare providers must draw on pertinent insights from the entire field of science. An effective training program must additionally introduce future healthcare workers to the science of placebos. ${ }^{24}$ Misunderstandings concerning placebo interventions might open the gate for their misuse, consequently risking future nurses and physicians harmonious team work and attitudes to practice and placing patients at risk of deception. ${ }^{25}$ Hence, a careful exploration of knowledge, attitude, and beliefs of future healthcare providers is 
imperative, consequently relevant evidence based recommendation for health profession educators could be achieved.

To sum up, although there is great evidence from an overabundance of research studies dealing with placebo and placebo effects, empirical investigations on the knowledge, beliefs, and attitudes of nursing and medical students concerning contemporary use of placebos in clinical practice are sparse. ${ }^{2}$ Carefully planned, questionnaire-based quantitative surveys could provide additional opportunities to share knowledge and exchange perspectives so we can tackle the complex nature and far reaching implications of the use of placebos in the clinic. Therefore, this study aimed at exploring knowledge, attitude, and beliefs of nursing and medical university students regarding placebo intervention in clinical practice.

\section{Materials and Methods Study Design and Setting}

A descriptive comparative - cross-sectional research design was utilized in the current study. This design aimed at describing and comparing knowledge, attitude, and beliefs about placebo intervention among nursing and medical university students at King Saud Bin Abdulaziz University for Health Sciences, Jeddah. The data comparisons and distributions of variables were studied at one point of a time without any further attempts of repeated measurements.

\section{Population and Sample Size}

A convenient sample of 96 nursing and 91 medical students were recruited. Inclusion criteria were being active B.Sc.N students registered in either medical or nursing colleges, finished professional years, and started professional years of study. Student interns were also invited for participation.

\section{Data Collection and Procedure}

Two paper and pencil self-report questionnaires were utilized for collecting data pertinent to the study. The first was the sociodemographic data sheet, that elicited information related to participant's age, gender, marital status, education level, education program, internship training site and duration, and completion of ethics course studies.

The second instrument was a 32-item questionnaire that was devised to collect data pertaining to research participants' knowledge, attitude, and beliefs of placebo use in clinical practice. This instrument was developed from the evidence-based literature as well as previous studies of placebo beliefs among nurses and physicians. Relevant articles were searched in CINAHL, PubMed, EMBASE, and Science direct by tracking citations. Relevant studies were identified using the following search words: placebo use, placebo intervention, placebo knowledge, placebo beliefs, placebo attitude, survey, and questionnaire.

The questionnaire was divided into three parts: knowledge (16 closed-ended items), beliefs (11 main closed ended questions which contained many other sub-items); and attitude (5 items). A pilot study was conducted using 20 nursing and medical students for testing the clarity, appropriateness, and feasibility of the developed questions. Content and construct validity were ensured through using experts in a medical education and practice fields and exploratory factor by an expert in psychometric analysis. Reliability analysis for the developed questionnaire revealed a Cronbach's alpha of 0.76 .

\section{Ethical Consideration}

The study proposal was submitted for scientific and IRB approval to the college of nursing and King Abdullah International Medical Research Centre (KAIMRC). Approval was received from both institutions. Investigators had approached nursing and medical students from both respective colleges in King Saud bin Abdul Aziz University for Health Sciences, Jeddah. Participants received an invitation letter explaining the aim, purpose, and procedure for research study. Moreover, they were informed and assured about their ethical rights as research participants. Researchers explained to them that their participation is voluntary and that they have the right to withdraw at any time from study without any penalties. They were also informed that their identity will totally be kept anonymous, they would not be required to spell names, badge, or academic numbers or any sort of identifications. Subjects' responses were only accessed by the research investigators and data were dealt with as aggregate rather than individual scores.

\section{Statistical Analysis}

Data management was carried out using the Statistical Package for Social Science (SPSS) program version 22. Data analysis included: descriptive statistics to summarize information obtained from study participants (means, standard deviations, frequencies, percentages, ... etc), and inferential statistics to compare variations in responses among nursing and medical students from both colleges 
(Chi-square, $t$-test). The statistical significance level was set at $P<0.05$ with a two tailed hypothesis.

\section{Results}

Concerning sociodemographic data, the mean age was $22.74 \pm 3.07$ for nursing students and $22.70 \pm 2.05$ for medical students. Percentage distribution of marital status per profession showed that $45.25 \%$ of nursing students and $43.58 \%$ of medical students were singles. Fifty-seven medical and nursing students $(32.60 \%)$ were in levels $5-6,26.90 \%$ were in levels $7-8$, and $28 \%$ were interns. Moreover, $12.5 \%$ medical students were recruited from levels 9-14. The total number of students who studied ethics from both colleges was 168 (89.9\%) (Table 1).

\section{Knowledge of Placebo Use}

As shown in Table 2, overall students' knowledge score of placebo was low. Nursing students showed significantly higher knowledge scores compared to the medical students (53.75 for nursing students compared to 49.38 for medical students). Analysis of students' knowledge about placebo revealed that College followed by colleagues were the most important sources. Almost half of the students identified College as their main source of knowledge for placebo and quite a number reported that they heard about placebo from their colleagues (Figure 1).

\section{Beliefs of Placebo Use in Clinical Practice} Concerning students' beliefs on placebo effectiveness, as shown in Table 3 , there was a statistically significant difference between nursing and medical students $(P<0.000)$. Quite a good number $54.3 \%$ of nursing students believed it is sometimes effective compared to $81.5 \%$ of medical students, while only $25.5 \%$ of nursing students believed that placebo is usually effectivecompared to only $15.2 \%$ of medical students. The majority of students (78.4\%) agreed that physical complains gets better by believing in the effectiveness of the placebo therapy.

The current study also measured students' beliefs on benefits of placebo in treatment of certain health problems (Table 4). There was a statistically significant difference between nursing and medical students concerning beliefs about effectiveness of placebo in managing mental or emotional disorders, rheumatological problems, cancer, cardiovascular disorders, and infectious diseases. A high percentage $(32.8 \%)$ of medical students' believed that the placebo effect on managing mental problems is only psychological, compared to only $19.1 \%$ of nursing students.
While $17.5 \%$ of nursing students attributed the effect following placebo administration to both psychological and physiological influences, only $11.5 \%$ of the medical students believed this.

Concerning management of rheumatological problems, many medical students (16\%) believed the psychological benefit of placebo treatment; conversely, $12.7 \%$ said they "do not know". Among nursing students, 11.6\% believed in the psychological benefit, and $11 \%$ stated that placebo has both physical and psychological effects. In total, $27.6 \%$ of medical and nursing students agreed that placebo has a psychological benefit and $22.7 \%$ of students did not know. Regarding placebo effects on cancer problems, a total percentage of 31.7 students agreed that placebo has a psychological benefit while $24.4 \%$ chose neither compared to $13.9 \%$ of nursing students.

In treating cardiovascular disorder, similar responses were shown among the students from both disciplines, a total of $26 \%$ of students agreed that placebo has a psychological benefit while a total of $22.7 \%$ of students did not know. In infectious disease, $19.7 \%$ of medical students stated "neither", and $13.1 \%$ stated psychological benefit. However, $12.6 \%$ of nursing student stated "both" and $10.9 \%$ stated "psychological" and "did not know". In gastrointestinal disorder, $17.9 \%$ of medical students agreed on the "psychological benefit", 10.1\% stated that they "do not know". Among nursing students, 16.8\% believed that it is mainly the psychological benefit, while $12.8 \%$ believed in "both" the physiological and psychological benefits.

In recovery from drug addiction, the results show almost similar beliefs among medical and nursing students, $20.1 \%$ of medical students stated placebo has a psychological benefit compared to $19 \%$ of nursing students, while $15.1 \%$ and $6.2 \%$, respectively, identified "both". Moreover, 7.3\% of medical students and 5.6\% stated that they "do not know".

In managing neurological problems, the result showed that $19.4 \%$ of medical students believed that placebo has a psychological benefit and 10.6\% stated "do not know". However, $21.7 \%$ of nursing students believed in its psychological benefit and $9.8 \%$ did not know. The result of immune problems or allergies showed that $13.9 \%$ of medical students and $13.3 \%$ of nursing students stated psychological.

Concerning the type of placebo use in clinical practice, Table 5 shows almost similar results between medical and nursing students concerning the acceptance of pure and 
Table I Sociodemographic Background for Study Respondents $(n=187)$

\begin{tabular}{|c|c|c|c|c|c|c|}
\hline \multicolumn{2}{|l|}{ Variable } & \multicolumn{2}{|l|}{ Profession } & \multirow[t]{3}{*}{ Total Mean (SD) } & \multirow[t]{3}{*}{$t$} & \multirow[t]{3}{*}{$P$} \\
\hline & & \multirow{2}{*}{$\begin{array}{l}\text { Nursing, N=96 } \\
M \text { (SD) }\end{array}$} & \multirow{2}{*}{$\begin{array}{l}\text { Medical, N=9 | } \\
M(S D)\end{array}$} & & & \\
\hline & & & & & & \\
\hline Age & $\mathrm{Cl}(-0.75-0.83)$ & $22.74(3.07)$ & $22.70(2.05)$ & $22.73(2.6)$ & -.002 & 0.99 \\
\hline Intern duration & $\mathrm{Cl}(-2.96-0.93)$ & $7.09(3.95)$ & $8.10(1.80)$ & $7.56(3.1)$ & -1.05 & 0.29 \\
\hline \multicolumn{2}{|l|}{ Variable } & $\mathbf{N}(\%)$ & $\mathbf{N}(\%)$ & Total N (\%) & $\chi^{2}$ & $P p$ \\
\hline Gender & $\begin{array}{l}\text { Male } \\
\text { Female }\end{array}$ & $\begin{array}{l}0(0.0) \\
96(50.8)\end{array}$ & $\begin{array}{l}91(49.2) \\
0(0.0)\end{array}$ & $187(100.0)$ & 183.04 & 0.000 \\
\hline Marital status & $\begin{array}{l}\text { Single } \\
\text { Married } \\
\text { Divorced }\end{array}$ & $\begin{array}{l}81(45.3) \\
14(7.8) \\
0(0)\end{array}$ & $\begin{array}{l}78(43.6) \\
5(2.8) \\
I(0.6)\end{array}$ & $\begin{array}{l}159(88.8) \\
19(10.6) \\
1(0.6)\end{array}$ & 4.66 & 0.10 \\
\hline Education level & $\begin{array}{l}5-6 \\
7-8 \\
9-14 \\
\text { Interns }\end{array}$ & $\begin{array}{l}34(19.4) \\
31(17.7) \\
1(0.6) \\
29(16.6)\end{array}$ & $\begin{array}{ll}23 & (13.1) \\
16 & (9.1) \\
21 & (12.0) \\
20 & (11.4)\end{array}$ & $\begin{array}{l}57(32.6) \\
47(26.9) \\
8(12.6) \\
49(28.0)\end{array}$ & 26.04 & 0.000 \\
\hline Education program & $\begin{array}{l}\text { Stream } 1 \\
\text { Stream } 2\end{array}$ & $\begin{array}{l}73(47.4) \\
23(14.9)\end{array}$ & $\begin{array}{l}44(28.6) \\
14(9.1)\end{array}$ & $\begin{array}{l}\text { II } 17(76.0) \\
37(24.0)\end{array}$ & 0.001 & 0.98 \\
\hline Study ethics & $\begin{array}{l}\text { Yes } \\
\text { No }\end{array}$ & $\begin{array}{l}77(4 I .2) \\
19(10.2)\end{array}$ & $\begin{array}{l}91(48.7) \\
0(0.0)\end{array}$ & $\begin{array}{l}168(89.9) \\
19(10.1)\end{array}$ & 20.26 & 0.000 \\
\hline Intern training site & $\begin{array}{l}\text { Surgical } \\
\text { others }\end{array}$ & $\begin{array}{l}10(20.4) \\
19(38.8)\end{array}$ & $\begin{array}{l}4(8.2) \\
16(32.7)\end{array}$ & $\begin{array}{l}14(28.6) \\
35(7 \mid .4)\end{array}$ & 1.22 & 0.27 \\
\hline
\end{tabular}

Table 2 Mean Placebo Knowledge Among Nursing and Medical Students

\begin{tabular}{|l|l|l|l|l|l|}
\hline Profession & Mean \% & SD & Cl & $\boldsymbol{t}$ \\
\hline Nursing Students & 53.75 & 13.00 & $(0.46-8.29)$ & & 2.21 \\
Medical Students & 49.38 & 14.05 & & & 0.029 \\
\hline
\end{tabular}

impure placebo. Forty-one per cent of nursing students accepted pure placebo compared to $41.6 \%$ of medical students. On the other hand, most of the medical and nursing students similarly did not accept the use of impure placebo in clinical practice $(32.8 \%$ and $25.9 \%$, respectively).

With regard to the ethical and legal legitimacy of placebo use, significant differences between nursing and medical students were shown concerning pure placebo ineffectiveness, deceiving effect, and acceptability ( $P=0.001,0.044$, and 0.009 , respectively). The majority of respondents among medical students $(24.6 \%)$ disagreed that pure placebo is ineffective compared to $21.0 \%$ of nursing students. Furthermore, $22.4 \%$ of medical students agreed that using pure placebo is not deceiving and must not be rejected. However, $23.6 \%$ of nursing student are uncertain whether it is deceiving or not. Almost thirty per cent $(29.4 \%)$ of medical students agreed that pure placebo could be used as long as physicians and patients work together, while $22.7 \%$ of nursing students were uncertain (Table 6).

Table 7 shows no significant difference between medical and nursing students with regard to ethical and legal legitimacy of impure placebo use. A total of 45 respondents $(37.5 \%)$ agreed that it was considered ineffective (22.5\% of medical students versus $15.8 \%$ of nursing students). Fifty-three respondents (45.3\%) agreed that impure placebo entails deception $(26.5 \%, 18.8 \%$; medical and nursing students, respectively). Regarding the belief that placebo must be rejected in principle of legal concern, 58 (47.6\%) students agreed on that and this constituted $24.6 \%$ of medical compared to $23.0 \%$ of nursing students. 


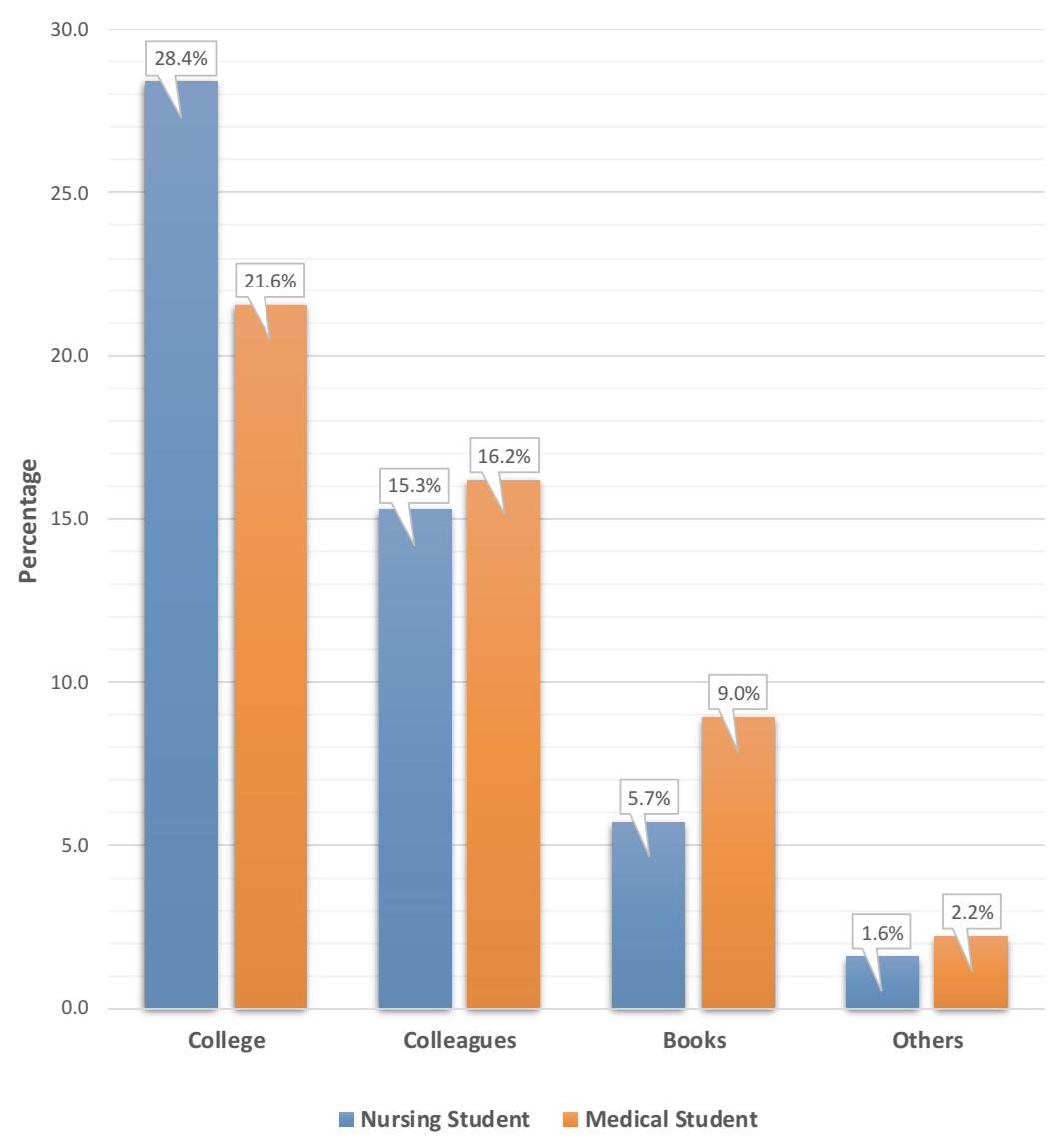

Figure I Sources of Students' Knowledge of Placebo.

Moreover, most medical and nursing students were uncertain $(41.4 \%)$ toward the use of impure placebo as long as the physician and patients work together, $22.0 \%$ medical, $19.5 \%$ nursing students; respectively.

Twenty-two percent of medical students agreed that the impure placebo is acceptable in terms of patient's benefit and a similar percentage were uncertain. On the other hand, $16.1 \%$ of nursing students were uncertain and only $14.4 \%$ considered impure placebo as acceptable.

There were statistically significant differences among medical and nursing students concerning using placebo intervention in clinical practice as a supplement, or for stopping patients' complaints and maintaining relationship with patients, or before the next scheduled medication dosage (Table 8). Both medical and nursing students held similar beliefs concerning the use of placebo for calming patients, after "unjustified" demand for medication, after all clinical treatment was exhausted, as a diagnostic tool and as a protective way to avoid patient addiction.

Table 9 shows students' beliefs on placebo use for managing different signs and symptoms. A similarly high agreement was found among medical and nursing students

Table 3 Nursing and Medical Students' General Beliefs on Placebo Interventions

\begin{tabular}{|c|c|c|c|c|c|c|}
\hline \multicolumn{2}{|l|}{ Variable } & \multicolumn{2}{|c|}{ Profession } & \multirow{2}{*}{$\begin{array}{l}\text { Total } \\
\text { N (\%) }\end{array}$} & \multirow[t]{2}{*}{$\chi^{2}$} & \multirow[t]{2}{*}{$P$} \\
\hline & & Nursing & Medical & & & \\
\hline Placebo effectiveness & $\begin{array}{l}\text { Usually effective } \\
\text { Sometimes effective } \\
\text { Never effective } \\
\text { I do not know }\end{array}$ & $\begin{array}{l}24(25.5) \\
51(54.3) \\
14(14.9) \\
5(5.3)\end{array}$ & $\begin{array}{l}14(15.2) \\
75(81.5) \\
1(1.1) \\
2(2.2)\end{array}$ & $\begin{array}{l}38(20.4) \\
126(67.7) \\
15(8.1) \\
7(3.8)\end{array}$ & 19.73 & 0.000 \\
\hline Physical complaints get better by believing in effectiveness of therapy & $\begin{array}{l}\text { Yes } \\
\text { No }\end{array}$ & $\begin{array}{l}67(72.0) \\
26(28.0)\end{array}$ & $\begin{array}{l}78(84.8) \\
14(15.2)\end{array}$ & $\begin{array}{l}145(78.4) \\
40(21.6)\end{array}$ & 4.43 & 0.035 \\
\hline
\end{tabular}


Table 4 Nursing and Medical Students' Beliefs Regarding Placebo Use for Managing Medical Conditions

\begin{tabular}{|c|c|c|c|c|c|c|c|c|}
\hline \multicolumn{2}{|l|}{ Variable } & \multirow{2}{*}{$\begin{array}{l}\text { Psychological } \\
\mathbf{N}(\%)\end{array}$} & \multirow{2}{*}{$\begin{array}{l}\text { Physiological } \\
\mathbf{N}(\%)\end{array}$} & \multirow{2}{*}{$\begin{array}{l}\text { Both } \\
\mathbf{N}(\%)\end{array}$} & \multirow{2}{*}{$\begin{array}{l}\text { Neither } \\
\mathbf{N}(\%)\end{array}$} & \multirow{2}{*}{$\begin{array}{l}\text { Do Not Know } \\
\mathbf{N}(\%)\end{array}$} & \multirow[t]{2}{*}{$\chi^{2}$} & \multirow[t]{2}{*}{$\mathbf{P}$} \\
\hline & & & & & & & & \\
\hline Pain & $\begin{array}{l}\text { Nursing } \\
\text { Medical } \\
\text { Total N (\%) }\end{array}$ & $\begin{array}{l}43(23.9) \\
41(22.9) \\
84(46.7)\end{array}$ & $\begin{array}{l}12(6.7) \\
4(2.2) \\
16(8.9)\end{array}$ & $\begin{array}{l}32(17.8) \\
34(18.9) \\
66(36.7)\end{array}$ & $\begin{array}{l}\text { I }(0.6) \\
7(3.9) \\
8(4.4)\end{array}$ & $\begin{array}{l}4(2.2) \\
2(1.1) \\
6(3.3)\end{array}$ & 9.19 & 0.06 \\
\hline Mental or emotional disorder & $\begin{array}{l}\text { Nursing } \\
\text { Medical } \\
\text { Total N (\%) }\end{array}$ & $\begin{array}{l}35(19.1) \\
60(32.8) \\
95(51.9)\end{array}$ & $\begin{array}{l}10(5.5) \\
4(2.2) \\
14(7.7)\end{array}$ & $\begin{array}{ll}32 & (17.5) \\
21 & (11.5) \\
53 & (29.0)\end{array}$ & $\begin{array}{l}7(3.8) \\
2(1.1) \\
9(4.9)\end{array}$ & $\begin{array}{l}7(3.8) \\
5(2.7) \\
12(6.6)\end{array}$ & 14.54 & 0.006 \\
\hline Gastrointestinal disorder & $\begin{array}{l}\text { Nursing } \\
\text { Medical } \\
\text { Total N (\%) }\end{array}$ & $\begin{array}{l}30(16.8) \\
32(17.9) \\
62(34.6)\end{array}$ & $\begin{array}{l}16(8.9) \\
16(8.9) \\
32(17.9)\end{array}$ & $\begin{array}{l}23(12.8) \\
14(7.8) \\
37(20.7)\end{array}$ & $\begin{array}{l}10(5.6) \\
9(5.0) \\
19(10.6)\end{array}$ & $\begin{array}{l}11(6.1) \\
18(10.1) \\
29(16.2)\end{array}$ & 3.99 & 0.41 \\
\hline Recovery from drug addiction & $\begin{array}{l}\text { Nursing } \\
\text { Medical } \\
\text { Total N (\%) }\end{array}$ & $\begin{array}{l}34(19.0) \\
36(20.1) \\
70(39.1)\end{array}$ & $\begin{array}{l}7(3.9) \\
4(2.2) \\
I 1(6.1)\end{array}$ & $\begin{array}{l}29(16.2) \\
27(15.1) \\
56(31.3)\end{array}$ & $\begin{array}{l}11(6.1) \\
8(4.5) \\
19(10.6)\end{array}$ & $\begin{array}{l}10(5.6) \\
13(7.3) \\
23(12.8)\end{array}$ & 1.76 & 0.77 \\
\hline Neurological & $\begin{array}{l}\text { Nursing } \\
\text { Medical } \\
\text { Total N (\%) }\end{array}$ & $\begin{array}{l}39(21.7) \\
35(19.4) \\
74(41.1)\end{array}$ & $\begin{array}{l}12(6.7) \\
6(3.3) \\
18(10.0)\end{array}$ & $\begin{array}{l}17(9.4) \\
16(8.9) \\
33(18.3)\end{array}$ & $\begin{array}{l}7(3.9) \\
13(7.2) \\
20(11.1)\end{array}$ & $\begin{array}{l}16(8.9) \\
19(10.6) \\
35(19.4)\end{array}$ & 4.28 & 0.37 \\
\hline Rheumatological & $\begin{array}{l}\text { Nursing } \\
\text { Medical } \\
\text { Total N (\%) }\end{array}$ & $\begin{array}{l}21(11.6) \\
29(16.0) \\
50(27.6)\end{array}$ & $\begin{array}{l}19(10.5) \\
6(3.3) \\
25(13.8)\end{array}$ & $\begin{array}{l}20(11.0) \\
15(8.3) \\
35(19.3)\end{array}$ & $\begin{array}{l}13(7.2) \\
17(9.4) \\
30(16.6)\end{array}$ & $\begin{array}{l}18(9.9) \\
23(12.7) \\
41(22.7)\end{array}$ & 9.89 & 0.04 \\
\hline Immune problems/allergies & $\begin{array}{l}\text { Nursing } \\
\text { Medical } \\
\text { Total N (\%) }\end{array}$ & $\begin{array}{l}24(13.3) \\
25(13.9) \\
49(27.2)\end{array}$ & $\begin{array}{l}\text { I3 (7.2) } \\
4(2.2) \\
\text { I7 (9.4) }\end{array}$ & $\begin{array}{l}19(10.6) \\
16(8.9) \\
35(19.4)\end{array}$ & $\begin{array}{l}19(10.6) \\
25(13.9) \\
44(24.4)\end{array}$ & $\begin{array}{l}18(10.0) \\
17(9.4) \\
35(19.4)\end{array}$ & 5.69 & 0.22 \\
\hline Cancer & $\begin{array}{l}\text { Nursing } \\
\text { Medical } \\
\text { Total N (\%) }\end{array}$ & $\begin{array}{l}25(13.9) \\
32(17.8) \\
57(31.7)\end{array}$ & $\begin{array}{l}14(7.8) \\
3(1.7) \\
17(9.4)\end{array}$ & $\begin{array}{l}17(9.4) \\
12(6.7) \\
29(16.1)\end{array}$ & $\begin{array}{l}16(8.9) \\
28(15.6) \\
44(24.4)\end{array}$ & $\begin{array}{l}19(10.6) \\
14(7.8) \\
33(18.3)\end{array}$ & 12.85 & 0.01 \\
\hline Cardiovascular disorder & $\begin{array}{l}\text { Nursing } \\
\text { Medical } \\
\text { Total N (\%) }\end{array}$ & $\begin{array}{l}21(11.6) \\
26(14.4) \\
47(26.0)\end{array}$ & $\begin{array}{l}15(8.3) \\
4(2.2) \\
19(10.5)\end{array}$ & $\begin{array}{l}20(11.0) \\
16(8.8) \\
36(19.9)\end{array}$ & $\begin{array}{l}14(7.7) \\
24(13.3) \\
38(21.0)\end{array}$ & $\begin{array}{l}23(12.7) \\
18(9.9) \\
41(22.7)\end{array}$ & 10.46 & 0.03 \\
\hline Infectious disease & $\begin{array}{l}\text { Nursing } \\
\text { Medical } \\
\text { Total N (\%) }\end{array}$ & $\begin{array}{l}20(10.9) \\
24(13.1) \\
44(24.0)\end{array}$ & $\begin{array}{l}15(8.2) \\
5(2.7) \\
20(10.9)\end{array}$ & $\begin{array}{l}23(12.6) \\
11(6.0) \\
34(18.6)\end{array}$ & $\begin{array}{l}15(8.2) \\
36(19.7) \\
51 \quad(27.9)\end{array}$ & $\begin{array}{l}20(10.9) \\
14(7.7) \\
34(18.6)\end{array}$ & 19.261 & 0.001 \\
\hline
\end{tabular}

on the use of placebo to manage withdrawal syndrome, sleep problems, and anxiety $(60.5 \%, 67.6 \%$, and $68.1 \%$; respectively). However, the result of the use of placebo to relieve pain and vertigo was significantly different between both groups ( $P=0.021,0.018$; respectively).

The results of the study concerning practices used to promote placebo effect showed significant differences for the practice of listening to the patient, expressing true caring and building rapport $(P=0.000,0.006,0.028$; respectively). The majority of students (84.4\%) agreed that listening carefully and thoroughly to the patient would promote the placebo effect, expressing true caring and concern for the patient and building provider-patient rapport was also believed by $67.4 \%$ and $76.2 \%$ of study respondents; respectively (Table 10).

\section{Students' Attitudes Toward Placebo Use in Clinical Practice}

Students' opinions and attitude on necessary information to be given to patients before placebo administration are shown in Table 11. There were statistically significant differences between study respondents on what the patients should be informed of when given placebo $(P=0.000)$. The highest percentage of study respondents agreed that patients should either be informed that they are 
Table 5 Acceptability of the Different Types of Placebo in Clinical Practice

\begin{tabular}{|l|l|l|l|l|l|l|}
\hline \multirow{2}{*}{ Variable } & \multicolumn{2}{|l|}{ Profession } & \multirow{2}{*}{$\chi^{2}$} \\
\cline { 2 - 6 } & Nursing & No & Medical & No & \\
\cline { 2 - 7 } & Yes & $14(8.1)$ & $72(41.6)$ & $16(9.2)$ & 0.09 & 0.77 \\
\hline Pure & $71(41.0)$ & $45(25.9)$ & $31(17.8)$ & $57(32.8)$ & 2.78 \\
\hline
\end{tabular}

Table 6 Ethical and Legal Legitimacy of Using Pure Placebo

\begin{tabular}{|c|c|c|c|c|c|c|c|}
\hline \multicolumn{2}{|l|}{ Variable } & \multicolumn{6}{|c|}{ Ethically Pure Placebo Consider as What? } \\
\hline & & \multirow{4}{*}{$\begin{array}{l}\text { Ineffective, } \\
\mathbf{N}=167 \\
35(21.0) \\
15(9.0) \\
50(29.9)\end{array}$} & \multirow{4}{*}{$\begin{array}{l}\text { Deceiving, } \\
\mathbf{N}=165\end{array}$} & \multirow{4}{*}{$\begin{array}{l}\text { Legal Concerns, } \\
\mathbf{N}=164 \\
24(14.6) \\
22(13.4) \\
46(28.0)\end{array}$} & \multirow{4}{*}{$\begin{array}{l}\begin{array}{l}\text { Used, } \\
N=163\end{array} \\
30(18.4) \\
48(29.4) \\
78(47.9)\end{array}$} & \multirow{4}{*}{$\begin{array}{l}\text { Acceptable, } \\
\mathbf{N}=167 \\
44(26.3) \\
48(28.7) \\
92(55.1)\end{array}$} & \multirow{4}{*}{$\begin{array}{l}\text { Traditional Component, } \\
\mathbf{N}=163 \\
29(17.8) \\
30(18.4) \\
59(36.2)\end{array}$} \\
\hline Agree & Nursing & & & & & & \\
\hline & Medical & & & & & & \\
\hline & Total N (\%) & & & & & & \\
\hline \multirow[t]{3}{*}{ Uncertain } & Nursing & $27(16.2)$ & $39(23.6)$ & $32(19.5)$ & $37(22.7)$ & $27(16.2)$ & $37(22.7)$ \\
\hline & Medical & $27(16.2)$ & $28(17.0)$ & $29(17.7)$ & $20(12.3)$ & $23(13.8)$ & $32(19.6)$ \\
\hline & Total N (\%) & $54(32.3)$ & $67(40.6)$ & $61(37.2)$ & $57(35.0)$ & $50(29.9)$ & $69(42.3)$ \\
\hline \multirow[t]{3}{*}{ Disagree } & Nursing & $22(13.2)$ & $22(13.3)$ & $25(15.2)$ & $13(8.0)$ & $13(7.8)$ & $14(8.6)$ \\
\hline & Medical & $4 \mathrm{I}(24.6)$ & $37(22.4)$ & $32(19.5)$ & $15(9.2)$ & $12(7.2)$ & $21(12.9)$ \\
\hline & Total N (\%) & $63(37.7)$ & $59(35.8)$ & $57(34.8)$ & $28(17.2)$ & $25(I 5.0)$ & $35(2 I .5)$ \\
\hline \multicolumn{2}{|l|}{$\chi^{2}$} & 13.725 & 6.255 & 1.070 & 9.315 & 0.528 & 1.725 \\
\hline \multicolumn{2}{|l|}{$P$} & 0.001 & 0.044 & 0.586 & 0.009 & 0.768 & 0.422 \\
\hline
\end{tabular}

given a medication or therapy $(31.5 \%)$, or placebo $(27.5 \%)$, or informing them that they are given a substance that may help and will not harm (25.1\%). Least agreement was on saying nothing to patients $(5.8 \%)$.
The general attitude of medical and surgical students showed some statistically significant differences concerning placebo prohibition, permitting it if research supports its efficacy and permitting it if the patient is notified that

Table 7 Ethical and Legal Legitimacy of Using Impure Placebo

\begin{tabular}{|c|c|c|c|c|c|c|c|}
\hline \multicolumn{2}{|l|}{ Variable } & \multicolumn{6}{|c|}{ Impure Placebo Considered as What? } \\
\hline & & \multirow{4}{*}{$\begin{array}{l}\text { Ineffective, } \\
N=120 \\
19(15.8) \\
26(21.7) \\
45(37.5)\end{array}$} & \multirow{4}{*}{$\begin{array}{l}\text { Deceiving, } \\
\mathbf{N}=117\end{array}$} & \multirow{4}{*}{$\begin{array}{l}\text { Legal Concerns, } \\
\mathbf{N}=\mathbf{I} 22 \\
28(23.0) \\
30(24.6) \\
58(47.6)\end{array}$} & \multirow{4}{*}{$\begin{array}{l}\begin{array}{l}\text { Used, } \\
\mathbf{N}=123\end{array} \\
13(10.6) \\
27(22.0) \\
39(31.7)\end{array}$} & \multirow{4}{*}{$\begin{array}{l}\text { Acceptable, } \\
\mathbf{N}=1 \text { I } 8 \\
17(14.4) \\
26(22.0) \\
43(36.4)\end{array}$} & \multirow{4}{*}{$\begin{array}{l}\text { Traditional Component, } \\
\mathbf{N}=107 \\
17(14.5) \\
13(11.1) \\
30(25.6)\end{array}$} \\
\hline Agree & Nursing & & & & & & \\
\hline & Medical & & & & & & \\
\hline & Total N (\%) & & & & & & \\
\hline \multirow[t]{3}{*}{ Uncertain } & Nursing & 14 (II.7) & $15(12.8)$ & $15(12.3)$ & $24(19.5)$ & $19(16.1)$ & $16(13.7)$ \\
\hline & Medical & $27(22.5)$ & $23(19.7)$ & $25(20.5)$ & $27(22.0)$ & $26(22.0)$ & $30(25.6)$ \\
\hline & Total N (\%) & $4 \mid(34.2)$ & $38(32.5)$ & $40(32.8)$ & $5 I(4 I .4)$ & $45(38.1)$ & $46(39.3)$ \\
\hline \multirow[t]{3}{*}{ Disagree } & Nursing & $16(13.3)$ & $8(6.8)$ & $9(7.4)$ & $15(12.2)$ & II (9.3) & $17(\mid 4.5)$ \\
\hline & Medical & $18(15.0)$ & $18(15.4)$ & $15(12.3)$ & $18(14.6)$ & $19(16.1)$ & $24(20.5)$ \\
\hline & Total N (\%) & $34(28.3)$ & $26(22.2)$ & $24(19.7)$ & $33(26.8)$ & $30(25.4)$ & $31(35.0)$ \\
\hline \multicolumn{2}{|l|}{$\chi^{2}$} & 1.34 & 0.87 & 1.45 & 1.89 & 0.23 & 3.59 \\
\hline \multicolumn{2}{|l|}{$\boldsymbol{P}$} & 0.512 & 0.646 & 0.486 & 0.388 & 0.889 & 0.166 \\
\hline
\end{tabular}


Table 8 Uses of Placebo in Clinical Practice

\begin{tabular}{|c|c|c|c|c|c|c|}
\hline \multicolumn{2}{|l|}{ Variable } & \multicolumn{2}{|c|}{ Profession } & \multirow{3}{*}{$\begin{array}{l}\text { Total } \\
\text { N (\%) } \\
155(83.8) \\
30(16.2)\end{array}$} & \multirow{3}{*}{$\frac{\chi^{2}}{1.51}$} & \multirow{3}{*}{$\begin{array}{l}P \\
0.219\end{array}$} \\
\hline & & \multirow{2}{*}{$\begin{array}{l}\text { Nursing } \\
81(43.8) \\
12(6.5)\end{array}$} & \multirow{2}{*}{$\begin{array}{l}\text { Medical } \\
74(40.0) \\
\text { I8 (9.7) }\end{array}$} & & & \\
\hline Calming patients & $\begin{array}{l}\text { Yes } \\
\text { No }\end{array}$ & & & & & \\
\hline After "unjustified" demand for medication & $\begin{array}{l}\text { Yes } \\
\text { No }\end{array}$ & $\begin{array}{l}60(32.6) \\
32(17.4)\end{array}$ & $\begin{array}{l}71(38.6) \\
21(11.4)\end{array}$ & $\begin{array}{l}|3|(7 \mid .2) \\
53(28.8)\end{array}$ & 3.21 & 0.073 \\
\hline After all clinical treatments were exhausted & $\begin{array}{l}\text { Yes } \\
\text { No }\end{array}$ & $\begin{array}{l}44(24.0) \\
48(26.2)\end{array}$ & $\begin{array}{l}37(20.2) \\
54(29.5)\end{array}$ & $\begin{array}{l}81(44.3) \\
102(55.7)\end{array}$ & 0.95 & 0.329 \\
\hline Used as supplemental treatment & $\begin{array}{l}\text { Yes } \\
\text { No }\end{array}$ & $\begin{array}{l}54(29.2) \\
39(21.1)\end{array}$ & $\begin{array}{l}42(22.7) \\
50(27.0)\end{array}$ & $\begin{array}{l}96(51.9) \\
89(48.1)\end{array}$ & 2.85 & 0.019 \\
\hline Used as diagnostic tool & $\begin{array}{l}\text { Yes } \\
\text { No }\end{array}$ & $\begin{array}{l}63(34.2) \\
30(16.3)\end{array}$ & $\begin{array}{l}62(33.7) \\
29(15.8)\end{array}$ & $\begin{array}{l}125(67.9) \\
59(32.1)\end{array}$ & 0.003 & 0.955 \\
\hline Stop patient complaints & $\begin{array}{l}\text { Yes } \\
\text { No }\end{array}$ & $\begin{array}{l}57(31.3) \\
35(19.2)\end{array}$ & $\begin{array}{l}26(14.3) \\
64(35.2)\end{array}$ & $\begin{array}{l}83(45.6) \\
99(54.4)\end{array}$ & 20.05 & 0.000 \\
\hline Maintain a good relationship with a patient & $\begin{array}{l}\text { Yes } \\
\text { No }\end{array}$ & $\begin{array}{l}53(28.8) \\
39(21.2)\end{array}$ & $\begin{array}{l}33(17.9) \\
59(32.1)\end{array}$ & $\begin{array}{l}86(46.7) \\
98(53.3)\end{array}$ & 8.73 & 0.003 \\
\hline Buy time before next regular dosage of medication & $\begin{array}{l}\text { Yes } \\
\text { No }\end{array}$ & $\begin{array}{l}52(28.1) \\
42(22.7)\end{array}$ & $\begin{array}{l}34(18.4) \\
57(30.8)\end{array}$ & $\begin{array}{l}86(46.5) \\
99(53.5)\end{array}$ & 5.99 & 0.014 \\
\hline Avoid patient addiction to any medication & $\begin{array}{l}\text { Yes } \\
\text { No }\end{array}$ & $\begin{array}{l}63(34.4) \\
28(15.3)\end{array}$ & $\begin{array}{l}59(32.2) \\
33(18.0)\end{array}$ & $\begin{array}{l}122(66.7) \\
61(33.3)\end{array}$ & 0.54 & 0.464 \\
\hline
\end{tabular}

Table 9 Signs and Symptoms for Which Placebo Might Be Used

\begin{tabular}{|c|c|c|c|c|c|c|}
\hline \multicolumn{2}{|l|}{ Variable } & \multicolumn{2}{|c|}{ Profession } & \multirow{3}{*}{$\begin{array}{l}\text { Total } \\
\text { N (\%) } \\
90(48.9) \\
93(50.5)\end{array}$} & \multirow{3}{*}{$\begin{array}{l}\chi^{2} \\
7.69\end{array}$} & \multirow{3}{*}{$\begin{array}{l}P \\
0.021\end{array}$} \\
\hline & & \multirow{2}{*}{$\begin{array}{l}\text { Nursing } \\
54(29.3) \\
38(20.7)\end{array}$} & \multirow{2}{*}{$\begin{array}{l}\text { Medical } \\
36(19.6) \\
55(29.9)\end{array}$} & & & \\
\hline Pain management & $\begin{array}{l}\text { Yes } \\
\text { No }\end{array}$ & & & & & \\
\hline Withdrawal syndrome in addicted patient & $\begin{array}{l}\text { Yes } \\
\text { No }\end{array}$ & $\begin{array}{l}58(31.4) \\
35(18.9)\end{array}$ & $\begin{array}{l}54(29.2) \\
38(20.5)\end{array}$ & $\begin{array}{l}\text { II } 2(60.5) \\
73(39.5)\end{array}$ & 0.26 & 0.610 \\
\hline Sleep problems & $\begin{array}{l}\text { Yes } \\
\text { No }\end{array}$ & $\begin{array}{l}64(35.2) \\
28(15.4)\end{array}$ & $\begin{array}{l}59(32.4) \\
31(17.0)\end{array}$ & $\begin{array}{l}123(67.6) \\
59(32.4)\end{array}$ & 0.33 & 0.563 \\
\hline Agitation & $\begin{array}{l}\text { Yes } \\
\text { No }\end{array}$ & $\begin{array}{l}48(25.8) \\
46(24.7)\end{array}$ & $\begin{array}{l}47(25.3) \\
45(24.2)\end{array}$ & $\begin{array}{l}95(5 \mathrm{I} .1) \\
91(48.9)\end{array}$ & 0.000 & 0.997 \\
\hline Anxiety & $\begin{array}{l}\text { Yes } \\
\text { No }\end{array}$ & $\begin{array}{l}67(36.2) \\
25(13.5)\end{array}$ & $\begin{array}{l}59(31.9) \\
33(17.8)\end{array}$ & $\begin{array}{l}126(68.1) \\
58(31.4)\end{array}$ & 2.61 & 0.272 \\
\hline Vertigo & $\begin{array}{l}\text { Yes } \\
\text { No }\end{array}$ & $\begin{array}{l}37(20.1) \\
55(29.9)\end{array}$ & $\begin{array}{l}22(12.0) \\
70(38.0)\end{array}$ & $\begin{array}{l}59(32.1) \\
125(67.9)\end{array}$ & 5.61 & 0.018 \\
\hline Others & $\begin{array}{l}\text { Yes } \\
\text { No }\end{array}$ & $\begin{array}{l}30(16.6) \\
60(33.1)\end{array}$ & $\begin{array}{l}19(10.5) \\
72(39.8)\end{array}$ & $\begin{array}{l}49(27.1) \\
132(72.9)\end{array}$ & 3.56 & 0.059 \\
\hline
\end{tabular}

he/she is receiving placebo $(P=0.000,0.000,0.010$; respectively). With regards to prohibiting its use, most nursing students agree that it should be prohibited
$(12.6 \%, 14.2 \%$, totally agree and agree, respectively), while a comparable percentage of medical students disagreed $(23.0 \%, 7.1 \%$ either totally disagree or disagree, 
Table 10 Practices That Promote Placebo Effects

\begin{tabular}{|c|c|c|c|c|c|c|}
\hline \multicolumn{2}{|l|}{ Variable } & \multicolumn{2}{|c|}{ Profession } & \multirow{3}{*}{$\begin{array}{l}\text { Total } \\
\text { N (\%) } \\
157(84.4) \\
29(15.6)\end{array}$} & \multirow{3}{*}{$\frac{\chi^{2}}{14.27}$} & \multirow{3}{*}{$\begin{array}{l}P \\
0.000\end{array}$} \\
\hline & & \multirow{2}{*}{$\begin{array}{l}\text { Nursing } \\
70(37.6) \\
24(12.9) \\
\end{array}$} & \multirow{2}{*}{$\begin{array}{l}\text { Medical } \\
87(46.8) \\
5(2.7)\end{array}$} & & & \\
\hline Listen carefully and thoroughly to the patient & $\begin{array}{l}\text { Yes } \\
\text { No }\end{array}$ & & & & & \\
\hline Express true caring and concern for the patient & $\begin{array}{l}\text { Yes } \\
\text { No }\end{array}$ & $\begin{array}{l}63(34.1) \\
30(16.2)\end{array}$ & $\begin{array}{l}78(42.2) \\
14(7.6)\end{array}$ & $\begin{array}{l}|4|(76.2) \\
44(23.8)\end{array}$ & 7.41 & 0.006 \\
\hline Physical examination of patient (independent of diagnostic purposes) & $\begin{array}{l}\text { Yes } \\
\text { No }\end{array}$ & $\begin{array}{l}65(35.5) \\
27(14.8)\end{array}$ & $\begin{array}{l}62(33.9) \\
29(15.8)\end{array}$ & $\begin{array}{l}127(69.4) \\
56(30.6)\end{array}$ & 0.14 & 0.711 \\
\hline Spending extra time with a patient & $\begin{array}{l}\text { Yes } \\
\text { No }\end{array}$ & $\begin{array}{l}55(29.7) \\
39(21.1)\end{array}$ & $\begin{array}{l}62(33.5) \\
29(15.7)\end{array}$ & $\begin{array}{l}117(63.2) \\
68(36.8)\end{array}$ & 1.84 & 0.175 \\
\hline Building provider-patient rapport & $\begin{array}{l}\text { Yes } \\
\text { No }\end{array}$ & $\begin{array}{l}55(29.9) \\
37(20.1)\end{array}$ & $\begin{array}{l}69(37.5) \\
23(12.5)\end{array}$ & $\begin{array}{l}124(67.4) \\
60(32.6)\end{array}$ & 4.85 & 0.028 \\
\hline Writing a prescription (independent of the medications prescribed) & $\begin{array}{l}\text { Yes } \\
\text { No }\end{array}$ & $\begin{array}{l}53(28.5) \\
4 I(22.0)\end{array}$ & $\begin{array}{l}62(33.3) \\
30(16.1)\end{array}$ & $\begin{array}{l}\text { II }(6 I .8) \\
7 I(38.2)\end{array}$ & 2.39 & 0.122 \\
\hline Praying with patient & $\begin{array}{l}\text { Yes } \\
\text { No }\end{array}$ & $\begin{array}{l}49(26.5) \\
44(23.8)\end{array}$ & $\begin{array}{l}44(23.8) \\
48(25.9)\end{array}$ & $\begin{array}{l}93(50.3) \\
92(49.7)\end{array}$ & 0.44 & 0.508 \\
\hline
\end{tabular}

Table I I Nursing and Medical Students' Attitude Toward Information to Be Given Before Placebo Administration

\begin{tabular}{|c|c|c|c|c|}
\hline \multicolumn{2}{|l|}{ Variable } & \multirow{2}{*}{$\begin{array}{l}\mathbf{N}(\%) \\
37(21.6) \\
17(9.9) \\
54(31.5)\end{array}$} & \multirow{2}{*}{$\frac{\chi^{2}}{26.189}$} & $\begin{array}{l}P \\
0.000\end{array}$ \\
\hline This is a medication/therapy & $\begin{array}{l}\text { Nursing } \\
\text { Medical } \\
\text { Total N (\%) }\end{array}$ & & & \\
\hline This is a placebo & $\begin{array}{l}\text { Nursing } \\
\text { Medical } \\
\text { Total N (\%) }\end{array}$ & $\begin{array}{l}31(18.1) \\
16(9.4) \\
47(27.5)\end{array}$ & & \\
\hline This is a medicine with no specific effect & $\begin{array}{l}\text { Nursing } \\
\text { Medical } \\
\text { Total N (\%) }\end{array}$ & $\begin{array}{l}9(5.3) \\
8(4.7) \\
17(9.9)\end{array}$ & & \\
\hline $\begin{array}{l}\text { It is a substance that may help and will } \\
\text { not harm }\end{array}$ & $\begin{array}{l}\text { Nursing } \\
\text { Medical } \\
\text { Total N (\%) }\end{array}$ & $\begin{array}{l}9(5.3) \\
34(19.9) \\
43(25.1)\end{array}$ & & \\
\hline I say nothing & $\begin{array}{l}\text { Nursing } \\
\text { Medical } \\
\text { Total N (\%) }\end{array}$ & $\begin{array}{l}5(2.9) \\
5(2.9) \\
10(5.8)\end{array}$ & & \\
\hline
\end{tabular}

respectively). Higher proportions of medical students totally agreed on the use of placebo based on research evidence compared to nursing students. An almost higher proportion of nursing students had a positive attitude toward permitting placebo if the patient is notified of receiving placebo compared to medical students. Moreover, medical and nursing students held a similar attitude toward permitting placebo if the experience supports its efficacy (Table 12).
Finally, there was a statistically significant difference between groups concerning their attitudes toward supporting the use of placebo. More nursing students positively supported placebo use instead of not giving treatment to patients while medical students were equally divided between agreeing and disagreeing on that. Study respondents' attitude toward benefits of using placebo for certain medical conditions or certain personality characteristics was not significantly different between both groups (Table 13). 
Table 12 General Attitude of Medical and Nursing Students Toward Permitting Use of Placebo in Clinical Practice

\begin{tabular}{|c|c|c|c|c|c|c|c|c|}
\hline Variable & & Totally Agree & Agree & No Idea & Disagree & Totally Disagree & $\chi^{2}$ & $\mathbf{P}$ \\
\hline Always prohibited & $\begin{array}{l}\text { Nursing } \\
\text { Medical } \\
\text { Total N (\%) }\end{array}$ & $\begin{array}{l}23(12.6) \\
9(4.9) \\
32(17.5)\end{array}$ & $\begin{array}{l}26(14.2) \\
\text { II }(6.0) \\
37(20.2)\end{array}$ & $\begin{array}{l}30(16.4) \\
17(9.3) \\
47(25.7)\end{array}$ & $\begin{array}{l}9(4.9) \\
42(23.0) \\
51(27.9)\end{array}$ & $\begin{array}{l}3(1.6) \\
13(7.1) \\
16(8.7)\end{array}$ & 43.401 & 0.000 \\
\hline Permitted if research supports its efficacy & $\begin{array}{l}\text { Nursing } \\
\text { Medical } \\
\text { Total N (\%) }\end{array}$ & $\begin{array}{l}19(10.3) \\
39(21.1) \\
58(31.4)\end{array}$ & $\begin{array}{l}40(21.6) \\
36(19.5) \\
76(41.1)\end{array}$ & $\begin{array}{l}31(16.8) \\
9(4.9) \\
40(21.6)\end{array}$ & $\begin{array}{l}2(1.1) \\
5(2.7) \\
7(3.8)\end{array}$ & $\begin{array}{l}\text { I (0.5) } \\
3(1.6) \\
4(2.2)\end{array}$ & 21.488 & 0.000 \\
\hline Permitted if the experience supports its efficacy & $\begin{array}{l}\text { Nursing } \\
\text { Medical } \\
\text { Total N (\%) }\end{array}$ & $\begin{array}{l}19(10.3) \\
21(11.4) \\
40(21.7)\end{array}$ & $\begin{array}{l}43(23.4) \\
41(22.3) \\
84(45.7)\end{array}$ & $\begin{array}{l}24(13.0) \\
22(12.0) \\
46(25.0)\end{array}$ & $\begin{array}{l}6(3.3) \\
3(1.6) \\
9(4.9)\end{array}$ & $\begin{array}{l}\text { I (0.5) } \\
4(2.2) \\
5(2.7)\end{array}$ & 3.013 & 0.556 \\
\hline Permitted if patient notified of receiving placebo & $\begin{array}{l}\text { Nursing } \\
\text { Medical } \\
\text { Total N (\%) }\end{array}$ & $\begin{array}{l}14(7.6) \\
12(6.5) \\
26(14.1)\end{array}$ & $\begin{array}{l}35(18.9) \\
25(13.5) \\
60(32.4)\end{array}$ & $\begin{array}{l}30(16.2) \\
20(10.8) \\
50(27.0)\end{array}$ & $\begin{array}{l}8(4.3) \\
16(8.6) \\
24(13.0)\end{array}$ & $\begin{array}{l}6(3.2) \\
19(10.3) \\
25(13.5)\end{array}$ & 13.242 & 0.010 \\
\hline
\end{tabular}

Table 13 General Attitude of Nursing and Medical Students Regarding Support for Use of Placebo

\begin{tabular}{|c|c|c|c|c|c|c|}
\hline \multicolumn{2}{|l|}{ Variable } & \multicolumn{2}{|c|}{ Profession } & \multirow{2}{*}{$\begin{array}{l}\text { Total } \\
\text { N (\%) }\end{array}$} & \multirow[t]{2}{*}{$\chi^{2}$} & \multirow[t]{2}{*}{$\mathbf{P}$} \\
\hline & & Nursing & Medical & & & \\
\hline \multirow[t]{2}{*}{ Support placebo use versus no treatment } & Yes & $63(34.2)$ & $46(25.0)$ & $109(59.2)$ & 6.505 & 0.011 \\
\hline & No & $29(15.8)$ & $46(25.0)$ & $75(40.8)$ & & \\
\hline \multirow[t]{2}{*}{ Placebos benefit certain medical conditions more } & Yes & $60(32.1)$ & $57(30.5)$ & $117(62.6)$ & 0.029 & 0.865 \\
\hline & No & $35(18.7)$ & $35(18.7)$ & $70(37.4)$ & & \\
\hline \multirow[t]{2}{*}{ Placebos have greater benefit for people with certain personality characteristics } & Yes & $70(37.6)$ & $73(39.2)$ & $143(76.9)$ & 1.117 & 0.291 \\
\hline & No & $25(13.4)$ & $18(9.7)$ & $43(23.1)$ & & \\
\hline
\end{tabular}

\section{Discussion}

Placebos have been vital therapeutic tools in clinical practice worldwide, with indispensable benefits both for patients and medical progress. To a various degree, placebo effects are existing in most aspects of medical practice and can be harnessed in order to improve health and well-being. ${ }^{4}$ However, its use in research and in clinical practice poses ethical and scientific debates among healthcare professionals. ${ }^{26}$ Practitioners' knowledge, attitude, and beliefs about placebo have a tremendous impact on the ethical use of placebo in medical practice. Extensive research in this sensitive area of medical practice is therefore mandated to uncover issues hindering its clinical use.

A review of previous research revealed significant heterogeneity across studies with respect to study participants, as most previous research focused on either practicing health professionals and/or their patients. Current research is therefore considered unique in addressing knowledge, attitude, and beliefs of nursing and medical university students regarding placebo intervention in clinical practice. Exploring background knowledge, attitude, and beliefs of medical and nursing students as being the future taskforce in the healthcare system can reveal current curriculum preparation of future health profession labors. The current study was conducted among 187 health profession nursing and medical students, their mean age was $22.73 \pm 3.06$ and $22.73 \pm 2.06$, respectively. The majority of students $(89.9 \%)$ had studied ethics and $59.5 \%$ of them were recruited from levels 5 to 8 .

\section{Knowledge of Placebo}

Growing knowledge of placebo is strongly associated with a variety of vital consequences regarding its effective use in clinical practice. The current study findings concerning knowledge of placebo however revealed a low level of knowledge among study participants. Nursing students showed significantly higher knowledge scores compared to the medical students. Almost half of the students 
identified college as their main source of knowledge for placebo and quite a number reported that they heard about placebo from their colleagues. Given the big contribution of placebos to health management outcomes, health practitioners must be ready to understand the effects and mechanisms of action of these therapeutic interventions. ${ }^{27}$

Previous research findings consistently suggest that adult patients are open to placebo use, but that their attitudes are shaped by the purpose of treatment, relationship with, expectations, and knowledge of healthcare professionals. ${ }^{22,28}$ Miller and Miller ${ }^{4}$ reported that promotion of placebo responses can enhance certain patient outcomes, and knowledgeable nurses and physicians should take on this task. Understanding the placebo effect is a prerequisite for improving healthcare. ${ }^{4}$ Despite that, Sheldon and OpieMoran $^{29}$ added that almost nothing is taught in medical faculties or postgraduate coaching about placebo responses and the effect of health practitioner attitudes and behaviors that seems important for effective treatment.

\section{Beliefs About Placebo Use in Clinical Practice}

Moreover, Palese et al., ${ }^{16}$ in a recent discussion paper, identified several contextual factors that influence clinical outcomes as beliefs, and behaviours of healthcare providers; expectations, preferences and previous experience. Concerning participants' beliefs on placebo effectiveness, the study showed a statistically significant difference among students. The majority of students believed that it is sometimes effective, while a smaller proportion think it is either usually or never effective at all. In addition, the majority of students (78.4\%) agreed that physical complaints get better by believing in the effectiveness of the placebo therapy. In fact, the benefits from medical treatments is a function both of the specific efficacy of the treatment itself and the therapeutic effects from the clinical context, known as "the placebo effect". The placebo effect can enhance the benefit of known effective treatment interventions by means of various psychological and neurobiological mechanisms. ${ }^{4}$ Nurses and physicians should deliberately promote placebo effects by boosting clinical attention to patients and adhering to the traditional humanistic side of caring. ${ }^{4}$ The placebo positive response could be prompted with the aid of the interaction between patients and caregiver through traditional conditioning and positive expectations about outcome in many conditions. ${ }^{29}$

The majority of the study participants also believed in the placebo's major psychological mechanism and to a lesser extent the physiological effects for managing different health problems. Similarly, Hull et $\mathrm{al}^{22}$ explained that the placebo effect is a multifaceted interaction of psychosocial aspects, human relationships, and preconceptions. ${ }^{22}$ Schedlowski et $\mathrm{al}^{27}$ emphasized that placebo effects have advanced as crucial tools to comprehend brain mechanisms that associate cognitive and psychological components with perceptions of symptom and organ functioning. In congruence, Locher et $\mathrm{al}^{30}$ also draw great attention to the strong relationship between psychotherapy and placebo.

To enhance patient outcomes, nurses and physicians ought to consider the potential placebo responses that may arise throughout their clinical encounters with patients. ${ }^{4}$ The study showed a mutual agreement between students in relation to effective use of placebo for calming patients, managing patient's "unjustified" demand for medication, and avoiding patient addiction to medications, especially pain killers. While nursing students held a stronger belief compared to medical students on the effectiveness of placebo use as supplemental medication, for managing non-specific complaints, maintain a good relationship with a patient and buying time before the next regular dosage of medication. Furthermore, the study explored the students' beliefs concerning the effect of placebo on managing specifically reported clinical signs and symptoms. A high agreement was found between medical and nursing students for the use of placebo to manage withdrawal syndrome, sleep problems, and anxiety $(60.5 \%, 67.6 \%, 68.1 \%$, respectively). However, beliefs on the efficacy of placebo to relieve pain and vertigo were significantly different between both groups ( $P=0.021,0.018$, respectively). Rossettini et $\mathrm{al}^{31}$ agreed that placebo effects are capable of modulating pain. Moreover, Laverdure-Dupont et $\mathrm{al}^{32}$ reported lower nocturnal pain and fewer sleep disturbances following placebo induction which were explained in light of analgesia expectations developed before sleep. In the same vein, Cadorin et $\mathrm{al}^{15}$ reported that physiological and psychological therapeutic effects of contextual factor were mostly reported in treating insomnia, chronic pain, drug/medication addiction, oncological problems, acute pain, emotional disorders, sexual problems, cardiovascular problems, and cognitive disorders.

With regard to mental and emotional disorders, medical students believed that placebo have a psychological benefit while nursing students had a strong belief of its both psychological and physiological effects. Feffer et al's ${ }^{33}$ study on depressed patients for the acceptability of placebo showed that the majority of the study group were willingness to 
waive their right to informed consent for placebo treatment if they were to suffer another depressive episode. On a large meta-epidemiological study, Salanti et $\mathrm{al}^{34}$ reported that the therapeutic response to antidepressants was on average smaller and dropouts were more likely when a placebo arm was included in a trial. They added that decreased patient expectations might explain this phenomenon. Belcher et $\mathrm{al}^{35}$ contended that the placebo effect is a powerful determinant of health outcomes in clinical disease treatment and management and argue that clinical trials of the placebo response in neuropsychiatric diseases has important clinical relevance. They $^{35}$ further added that placebo has already been shown to be effective for improving outcomes in a huge range of healthcare settings, and can further be an effective treatment of chronic diseases such as neuropsychiatric disorders, including depression, anxiety disorders, and substance use disorder.

Regarding the ethical and legal legitimacy of placebo use, nursing and medical students significantly differed concerning pure placebo effectiveness/ineffectiveness, its deceiving effect, and its acceptability. The majority of respondents disagreed that pure placebo should be considered ineffective. Medical students reported that pure placebo should not be considered as deceiving and can be used as long as physician and patients work together. However, the majority of nursing students were uncertain whether pure placebo is deceiving or not and whether it can be as long as physicians and patients work together. Feffer et al.'s ${ }^{33}$ study showed that the majority of patients did not consider placebo treatment to be a deceit.

In contrast, no significant difference was found between medical and nursing students with regard to ethical and legal legitimacy of using impure placebo. However, 29.9\% agreed that they considered pure placebo ineffective compared to $37.5 \%$ for impure placebo, and $23.6 \%$ of respondents agreed that pure placebo entails deception versus $45.3 \%$ for pure type. However, most medical and nursing students were uncertain (41.4\%) toward the use of impure placebo as long as physicians and patients work together. In fact, quite a good number $(28.0 \%)$ of students agreed that pure placebo must be rejected in principle of legal concerns compared to $47.5 \%$ for impure placebo. Cadorin et al ${ }^{15}$ showed that nursing students considered the use of a placebo as ethically acceptable when it exerted psychological benefits or when the clinical experience showed its effectiveness. Thus, there is a concrete need to revise some physician models and create guidelines to meet the current needs of patients and physicians alike. ${ }^{22,28}$
Moreover, the results of the study concerning practices believed to promote the placebo effect showed that the majority of students agreed on the importance of listening carefully and thoroughly to the patient, expressing true caring and concern for the patient, and building provider-patient rapport would promote the placebo effect. On the same vein, Sheldon and Opie-Moran ${ }^{29}$ reported that effective interactions with the patient, including paying focused attention and obtaining a detailed history, are considered as components of effective placebo intervention. Moreover, Cadorin et al ${ }^{15}$ reported "empathetic therapeutic alliance", the "patient-centered approach", and "verbal communication" as the highest trusted contextual factors enhancing placebo response, while the lowest effects were attributed to: the uniform, adequate environmental architectural design, and professional reputation.

\section{Attitudes Toward Placebo Use in Clinical Practice}

In general, using placebo in practice is seen to endanger patients' surgeon trust, from the point of view of medical students, while nursing students continue to consider it as a mean of deception. Locher et $\mathrm{al}^{30}$ added that it is of most importance for the clinical practice that patients should have a secured right to be furnished with truthful information about how treatments work. Information about the nature of therapy - such as the importance. Non-disclosure of information about possible adverse effects also denies patients the right of making an informed decision. This poses an extra complex ethical dilemma between respect for autonomy and beneficence. ${ }^{4}$ Nursing students held a positive strong attitude toward the need for informing the patient that placebo is medication/therapy. Previous studies indicated that open-label placebos (that patients know are placebos) can provoke behavioral and clinical outcome changes. ${ }^{12}$ Colloca and Howick ${ }^{12}$ further added that placebos without deception would supersede ethical obstacles to their clinical use. Indeed, a trustworthy and empathic doctor-patient communication safeguards from unwanted adverse effects. Healthcare providers should offer balanced information on the expected positive treatment effect and any associated side-effects. ${ }^{27}$

Experts particularly agreed on the importance of informing patients about placebo to maximize placebo effects. Medical students in the current study believed that it would be better to inform the patient that it is a substance that may help and will not harm. This was in agreement with the 
findings of Cadorin et al, ${ }^{15}$ who reported that about half of the students emphasized the need for informing the patient of its use as a treatment that can be helpful, which can reflect the consequence of an effective nursing education. Moreover, there was mutual agreements between nursing and medical students for using placebo if there is no other treatment available. Abou-Mrad and Tarabey ${ }^{26}$ contended that medical practitioners commonly fail to agree to a general outline that should guide the use of placebo, hence the process of placebo use will continue to be subject to the paternalistic assessments of medical professionals.

On the other hand, Belcher et $\mathrm{al}^{35}$ emphasized that strengthening expectations and improving pharmacological conditioning are promising strategies for promoting placebo effects in clinical practice. Expectations can impact the course of treatment by affecting the psychological and physiological responses to that treatment. Rossettini et $\mathrm{al}^{31}$ stated that placebo and nocebo effects are capable of producing adjustments at body different levels elicited by different contextual factors (CFs) existing in the therapeutic encounter between patient and healthcare providers. Among these CFs are patient's expectation, clinician's behavior, and belief. In addition, Colloca and Howick ${ }^{12}$ explained that patients' positive expectancies may in part account for the variability in pain experience and severity, adherence to treatment, and coping strategies. Careful appraisal of patients' anticipations and pretreatment experiences should therefore be carefully documented. The medical practitioner ought to be able to decide whether treatment expectations are helpful and whether pretreatment encounters may affect the treatment response. ${ }^{27}$

Concerning the attitude of medical and nursing students toward conditions permitting the use of placebo use, the study showed statistically significant differences for prohibiting its use, permitting it if research supports its efficacy, and permitting if the patient is notified that he is receiving placebo. Almost $30 \%$ of medical students totally disagree or agree that placebo should always be prohibited, compared to $26.8 \%$ of nursing students who held an opposite belief. On the other hand, $40.6 \%$ of medical students as opposed to $31.9 \%$ of nursing students stated that they totally agree for using placebo if research supports its efficacy. Nursing students supported its use if the patient is notified that he is receiving placebo. Finally, the majority of nursing students positively supported the use of placebo instead of not giving treatment to patients, while medical students were equally divided between agreeing and disagreeing on that. Study participants' attitude toward the benefit of placebo for certain medical conditions or to certain personality characteristics was similar between students.

On the contrary, Abou-Mrad and Tarabey ${ }^{26}$ found that all religious leaders (Christian and Muslim) were against the use of placebo in all instances, claiming that it was an immoral practice that was based on deceit and undermines the value of the human being. While the authors reported that a second group of professionals who were divided into two subgroups, first of them shared rejection of the use of placebo with the religious authorities. Unlike the religious authorities, the problem posed by this group of professionals focused on the fact that administering placebo was denying or experimenting with treatment, which they considered unacceptable. The other group of professionals accepted its use but only in certain circumstances including cases that were medically classified as non-life-threatening. Feffer et $\mathrm{al}^{33}$ added that foregoing the opportunity of placebo treatment, regardless of our finding that a tremendous number of patients would be interested in that option, may be unduly restricting the range of therapeutic interventions of the medication.

\section{Conclusion and Recommendations}

Despite the recent focus on evidenced-based practice, healthcare practitioners' knowledge and attitude of placebo is still relatively under-represented in the medical literature. ${ }^{4}$ Exploring knowledge, attitude, and beliefs of future healthcare companies was quintessential as applicable evidence primarily based recommendation for nursing and clinical educators could be achieved. In the current study, students quite frequently believe that placebo use has the power of positively altering the clinical outcome of patients. Current study findings also offered a unique opportunity to better study misunderstandings for placebo, which might open the gate for misuse and place patients at risk of deception. Furthermore, possessing the aptitudes to maximize placebo responses whereas minimizing nocebo responses is fundamental from a clinical application point of view. ${ }^{27}$ Taken together, information about placebo should be integral components within the curricula for health profession education.

The current findings have very important implications for nursing and medical curricula. We think that the time has come for clinicians to manage conscientiously and ethically placebo for the benefit of their patients and this should require possessing adequate knowledge, attitude, and beliefs about placebo. Placebos therefore should be an integral part of the curricula to ensure proper understanding and ethical use in clinical practice. 
Additionally, limited professional evidence-based guidelines on placebo use and the lack of information and training is restricting the use of the placebo in practice. Moreover, access to online training materials would assist in disseminating a consistent technique that maximizes the analgesic effect. Hence, developing a legislative code based on evidence-based and ethical recommendations is needed to properly guide placebo use for medical care.

\section{Disclosure}

An abstract for the study was presented at the 48th Global Nursing \& Healthcare Conference, March 4-6, 2019, Barcelona, Spain. The abstract was also published in Journal of Nursing \& Care, ISSN: 2167-1168.

The authors report no conflicts of interest in this work.

\section{References}

1. Fässler M, Gnädinger M, Rosemann T, Biller-Andorno N. Placebo interventions in practice: a questionnaire survey on the attitudes of patients and physicians. British J General Practice. 2011;61 (583):101-107. doi:10.3399/bjgp11x556209

2. Fässler M, Meissner K, Schneider A, et al. Frequency and circumstances of placebo use in clinical practice a systematic review of empirical studies. BMC Med. 2010;8:15. doi:10.1186/1741-7015-8-15

3. Kermen R, Hickner J, Brody H, et al. Family physicians believe the placebo effect is therapeutic but often use real drugs as placebos. Fam Med. 2010;42:636-642.

4. Miller LR, Miller FG. Understanding placebo effects: implications for nursing practice. Nurs Outlook. 2015;63(5):601-606. doi:10.1016/j.outlook.2015.03.002

5. Tilburt JC, Emanuel EJ, Kaptchuk TJ, et al. Prescribing "placebo treatments": results of national survey of US internists and rheumatologists. BMJ. 2008;337:a1938. doi:10.1136/bmj.a1938

6. Linde K, Atmann O, Meissner K, et al. How often do general practitioners use placebos and non-specific interventions? Systematic review and meta-analysis of surveys. PLoS One. 2018;13(8):e0202211. doi:10.1371/journal

7. AL-Jumaih A, Kadhim IA, AL-Seraya A, Nicholls A, Aal S. Placebo prescribing habits and views in a University Hospital; Published 2011 Available from: WebmedCentral.com.http://www.webmedcentral. com/article_view/587

8. Colloca L, Miller FG. Harnessing the placebo effect: the need for translational research. Philosophical Transactions Royal Society B. 2011;366(1572):1922-1930. doi:10.1098/rstb.2010.0399

9. Ortiz R, Hull SC, Colloca L. Patient attitudes about the clinical use of placebo: qualitative perspectives from a telephone survey. BMJ Open. 2016;6:e11012. doi:1136/bmjopen-2015-011012

10. Sliwinski J, Elkins GR. Enhancing placebo effects: insights from social psychology. Am J Clin Hypn. 2013;55(3):236-248. doi:10.1080/00029157.2012.740434

11. National Institutes of Health. The placebo effect in clinical practice; 2001. Available from: http:/grants.nih.gov/grants/guide/rfa-files/ RFA-AT-02-001.html. Accessed July 22, 2020.

12. Colloca L, Howick J. Placebos without deception: outcomes, mechanisms, and ethics. Int Rev Neurobiol. 2018;219-240. doi:10.1016/bs.irn.2018.01.005

13. Groll D. What you don't know can help you: the ethics of placebo treatment. J Appl Philos. 2011;28(2):188-202. doi:10.1111/j.14685930.2011.00517.x
14. Colloca L, Jonas WB, Killen J, Miller FG, Shurtleff D. Reevaluating the placebo effect in medical practice. Z Psychol. 2014;222(3):124127. doi:10.1027/2151-2604/a000177

15. Cadorin L, Rossettini G, Testa M, Geri T, Palese A. The awareness of contextual factors, placebo and nocebo effects among nursing students: findings from a cross-sectional study. Nurse Educ Pract. 2020;42:102670. doi:10.1016/j.nepr.2019.102670

16. Palese A, Rossettini G, Colloca L, Testa M. The impact of contextual factors on nursing outcomes and the role of placebo/nocebo effects: a discussion paper. Pain Rep. 2019;4(3):e716. doi:10.1097/PR9.0000000000000716

17. Kaptchuk TJ. Open-Label Placebo: reflections on a research agenda. Perspect Biol Med. 2018;61(3):311-334. doi:10.1353/pbm.2018.0045

18. Harris CS, Raz A. Deliberate use of placebos in clinical practice: what we really know. $J$ Med Ethics. 2012;38(7):406-407. doi:10.1136/medethics-2012-100695

19. Pugh J. Ravines and sugar pills: defending deceptive placebo use. OUP Academic; [Published December 10, 2014] Available from: https://aca demic.oup.com/jmp/article/40/1/83/2742964. Accessed July 22, 2020.

20. Chung KS, Price DD, Verne NG, Robinson ME. Revelation of a personal placebo response: its effects on mood, attitudes and future placebo responding. Pain. 2007;132(3):281-288. doi:10.1016/j.pain.2007.01.034

21. Stetler C Adherence, expectations and the placebo response: why is good adherence to an inert treatment beneficial? Psychology \& health; Published 2014 Available from: https://www.ncbi.nlm.nih. gov/pmc/articles/PMC3851940/. Accessed October 3, 2019.

22. Hull SC, Colloca L, Avins A, et al. Patients' attitudes about the use of placebo treatments: telephone survey. BMJ. 2013;347-375.

23. Baldwin MJ, Wartolowska K, Carr AJ. A survey on beliefs and attitudes of trainee surgeons towards placebo. BMC Surg. 2016;16:27. doi:10.1186/s12893-016-0142-5

24. Raz A, Guindi D. Placebos and medical education. MJM. 2008;11 (2):223-226.

25. Berger JT. Placebo medication use in patient care: a survey of medical interns. West J Med. 1999;170(2):93-96.

26. Abou-Mrad F, Tarabey L. Attitudes toward placebo use in lebanon. Clin Ther. 2015;37(5):1138-1145. doi:10.1016/j.clinthera.2015.02.023

27. Schedlowski M, Enck P, Rief W, Bingel U. Neuro-bio-behavioral mechanisms of placebo and nocebo responses: implications for clinical trials and clinical practice. Pharmacol Rev. 2015;67(3):697-730. doi:10.1124/pr.114.009423

28. Tandjung R, Tang H, Fässler M, et al. The patient's perspective of placebo use in daily practice: A qualitative study. Swiss Med Wkly. 2014;144:13899.

29. Sheldon R, Opie-Moran M. The placebo effect in cardiology: understanding and using It. Canadian J Cardiol. 2017;33(12):1535-1542. doi:10.1016/j.cjca.2017.09.017

30. Locher C, Gaab J, Blease C. When a placebo is not a placebo: problems and solutions to the gold standard in psychotherapy research. Front Psychol. 2018;9. doi:10.3389/fpsyg.2018.02317

31. Rossettini G, Carlino E, Testa M. Clinical relevance of contextual factors as triggers of placebo and nocebo effects in musculoskeletal pain. $B M C$ Musculoskelet Disord. 2018;19:1. doi:10.1186/s12891-018-1943-8

32. Laverdure-Dupont D, Rainville P, Renancio C, Montplaisir J, Lavigne G. Placebo analgesia persists during sleep: an experimental study. Prog Neuropsychopharmacol Biol Psychiatry. 2018;85:33-38. doi:10.1016/j.pnpbp.2018.03.027

33. Feffer K, Lichtenberg P, Becker G, Bloch Y, Netzer R, Nitzan U. A comparative study with depressed patients on the acceptability of placebo use. Gen Hosp Psychiatry. 2016;41:53-56. doi:10.1016/j.genhosppsych.2016.05.004

34. Salanti G, Chaimani A, Furukawa TA, et al. Impact of placebo arms on outcomes in antidepressant trials: systematic review and metaregression analysis. Int $J$ Epidemiol. 2018;47(5):1454-1464. doi:10.1093/ije/dyy076

35. Belcher AM, Ferré S, Martinez PE, Colloca L. Role of placebo effects in pain and neuropsychiatric disorders. Prog Neuropsychopharmacol Biol Psychiatry. 2018;87:298-306. doi:10.1016/j.pnpbp.2017.06.003 


\section{Publish your work in this journal}

Advances in Medical Education and Practice is an international, peerreviewed, open access journal that aims to present and publish research on Medical Education covering medical, dental, nursing and allied health care professional education. The journal covers undergraduate education, postgraduate training and continuing medical education including emerging trends and innovative models linking education, research, and health care services. The manuscript management system is completely online and includes a very quick and fair peer-review system. Visit http://www.dovepress.com/testimonials.php to read real quotes from published authors.

Submit your manuscript here: http://www.dovepress.com/advances-in-medical-education-and-practice-journal 